\title{
Isolationism versus Geopolitics: The Dual Role of the Eurasian Union in the System of Global Governance ${ }^{1}$
}

\author{
M. Bratersky
}

\begin{abstract}
Maxim Bratersky - Professor in the Department of International Affairs, National Research University Higher School of Economics; 20 Myasnitskaya, 101000 Moscow, Russian Federation; E-mail: mbratersky@hse.ru

This paper conceptualises the recent and ongoing efforts to create and develop the Eurasian Union, initiated by Russia, Belarus and Kazakhstan in 2011. Engaging with two major theoretical perspectives on this regional project, we aim to establish to what extent it is economic regionalism (interpreted also as an isolationist strategy), vis-à-vis Russia-led geopolitical motives, that drives the construction and potential expansion of the Eurasian Union. The political-economy debate of Eurasia goes beyond a common tariff area and a common market within the territory of the former USSR. Increasingly, it involves the establishment of a common monetary area. It appears that a new Silk Road is being laid with foundations for a new Eurasia - one of the global economic and political players of this century. In our analysis, the economic reasons pursued by Russia in the Eurasian initiative are in fact inseparable from the economic problems of geopolitical significance. We argue that overarching objective of Russian policy is to establish a regional economic fusion, with significant economic sovereignty and strong political influence; that is, the new centre of power in the global economy of the 21st century. Correspondingly, our analysis also suggests that while Russian integration policy in Eurasia has not been formulated in an anti-American way, if successful, the likely consequence will be that a significant segment of the global market will be withdrawn from under the economic dominance and political influence of Western-led economic blocks.
\end{abstract}

Key words: Eurasian Union; Global Governance

In December 2012, the United States Secretary of State Hillary Clinton, during a meeting with lawyers from non-governmental organizations in Dublin, commented on the Russian post-Soviet integration plans. She characterised the plans as "a move to re-Sovietize the region" and underlined that "we know what the goal is and we are trying to figure out effective ways to slow down or prevent it. ." It cannot be said that the words of the Secretary of State sparked a strong international reaction, but the Russian President 's Press Secretary, Dmitry Peskov, responded to them and described Clinton's words as showing "complete incompetence in the matters" taking place in the post-Soviet space. H. Clinton, during the rather politically incorrect commentary, led the discussion towards that a new USSR could be created under new names - like a Customs Union or a Eurasian Union. Currently, "a move to re-Sovietize the region" exists; "it's not going to be called that"; "it's going to be called a Customs Union; it will be called the Eurasian Union and all of that; but let's make no mistake about it. ${ }^{3 \text { " }}$ The spokesperson of the Department of State Victoria Nuland, was put under pressure to reiterate Secretary of State comments, but the response was limited to common generalities and she underlined that Secretary of State

${ }^{1}$ The article was submitted to the editors in February 2016.

${ }^{2}$ Clinton Calls Eurasian Integration An Effort To "Re-Sovietize". Available at: http://www.rferl.org/ content/clinton-calls-eurasian-integration-effort-to-resovietize/24791921.html (accessed 16 November 2016).

${ }^{3}$ Russia's representative at NATO responded to Clinton's words on the reestablishment of USSR. Available at: http://actualcomment.ru/news/51097/ (accessed 16 November 2016). (In Russian.) 
was at the time in a private, non-public, discussion. ${ }^{4}$ Nevertheless, it is clear that $\mathrm{H}$. Clinton said what she thinks and that leading politicians of the United States began to perceive the Russian post-Soviet plans in all seriousness. Recently, at the end of 2015 Jean-Claude Juncker, the President of the European Commission in his letter to Putin accepted Eurasian Union as a partner for the future dialogue with EU. ${ }^{5}$ The existence of the new integration clock in Eurasia has been acknowledged.

Today, American and European policies in the post-Soviet region stands at a crossroad. The future administration in the White House and politicians in Brussels can either continue the previous policy towards Russia, under which essentially, disregarded even the smallest degree of respect towards Russian regional interests by pursuing various technical objectives that ripped apart the post-Soviet space into individual segments, or accept Eurasian Union as a reality and start talking to him.

The proposed article aims to analyse the purpose of the Russian policy in regards to establishing integrational linkages in the post-Soviet space, as by examining the tasks, both the policy of integration and regionalisation could be applied. A second objective of this article will relate the goals of Russian policy in the region, with the foreign policy interests of the United States and EU, and determining the extent to which the objectives of the Russian and Western policy in the post-Soviet space are not contradictory or divergent.

This article refrains from discussing the Chinese factor in Eurasian policies of both Russia and the Eurasian Union, and United States and EU.

Our intention is to direct the arguments to the following conclusions:

1. Along with solving the constricting economic tasks, the Russian integration policy targets to address economic problems of geo-economic significance. The overarching objective of Russian policy is to establish a regional economic fusion, with significant economic sovereignty and strong political influence; that is the new centre of power.

2. Russian integration policy in Eurasia is not formulated in an anti-American way, but if it is successful the consequence will be that a part of the global market will be withdrawn from under the economic dominance and political influence of the USA. This line touches the financial and economic interests of the United States, but does not create a threat to their national security interests. It can be expected that the USA would counter Russia's integration policy, but this particular countermeasure will not be the US top priority. European Union has more intensives for opening a dialogue with the Eurasian Union and some form of cooperation between two blocks is more likely in the future.

\section{The Global Context of Eurasian integration}

It seems only yesterday international-theorists avidly argued with each other about the prospect that the sovereign state could vanish from world politics under the force of expanding global markets. Today this illusion has disappeared, the modern world evermore represents a huge bundle of political and economic zones: established in Europe, around the United States, China and India. In the heart of the post-Soviet space, Russia is also forming its own politicallyeconomic unification, which will imminently place it in the row alongside the giants of the $21^{\text {st }}$ century. CIS countries (except for Uzbekistan and Azerbaijan) among each other formed a free trade zone, the Customs Union amid Russia, Belarus and Kazakhstan is operational, and the

${ }^{4}$ Victoria Nuland, Spokesperson. Daily Press Briefing. Washington, DC. December 11, 2012. Available at: http://www.state.gov/r/pa/prs/dpb/2012/12/201811.htm\#RUSSIA (accessed 16 November 2016).

${ }^{5}$ TheletterofJunckertoPutinangered Lithuania.Availableat:http://www.dni.ru/polit/2015/11/20/321167. html (accessed 16 November 2016). (In Russian.) 
Common Economic Space project is launched. For continuation of the integration process and for a new level of output to be reached a supranational governing body has been formed - Eurasian Commission; active discussions are ongoing planning for the conception of an effective new association of the Eurasian Union and the accession of new members. Increasingly, the debate goes beyond talking simply about a common market within the territory of the former USSR, but also about the establishment of a common monetary area. Today a new Silk Road is being laid with foundations being shaped for a new Eurasia - one of the global economic and political players of this century.

How are the objectives of Russian integration policies in Eurasia formulated? Is Russia just trying to make itself and the surrounding region more competitive and economically more appealing on the global economic stage, or is Russia realising a completely different tactic?

Being the largest exporters of raw materials and energy, the primary states of the future Eurasian Union do not face the classic problem of competing with other countries for attracting foreign capital, as foreign capital has to compete for them. Under such circumstances, Russia's behaviour is unexplainable by the classical theory of state competition [Palan, 2007, pp. 47-69], therefore why does it need this project? As an additional shield against increasing international competition? Or the planned Union will aim to protect both the industry and the services of participating countries? Or the motivation for creating a new Union lies mainly in the cultural and political spheres?

\section{Economic and Political Benefits from Economic Integration and Motives Behind Russian Politics}

The main research approaches to the question of the effectiveness of regional economic groupings are embodied in economic and political sciences (or study of international relations). As the precondition is to ascertain the interests of participating-states of Eurasian integration, special attention should be given to approaches to asses the benefits of integration, since the size and nature of the benefits is the main incentive for integration.

Usually, when the goals of economic integration are discussed, the economic gains are placed at the forefront, which the participating-states presuppose to receive from the process. The original economic efficiency studies of integration schemes have emerged relatively a long time ago, in the 1950's. Among the classic works on this subject, one could recall books and articles by Viner [Viner, 1950], Meade [Meade, 1955] and Lipsey [Lipsey, 1960]; which show that the formation of regional integration schemes create more intensive trade flows amid the participating members in contrast to non-member states and due to this promotes more rapid wealth generation. These findings come from the classical theorems of political economy on trade profitability. Further, it is underlined that the creation of a regional economic organization expands the size of the internal market and gives member-states more cohesive 'market power' in contrast if they act alone. This, in turn, allows members to form the optimal tariff in relation to third-party countries [Krugman, 1993, pp. 58-89]. Common to all concepts of economic efficiency, the creation of regional economic groupings evolves around the idea that, such regional arrangements reduce "frictional-losses" in mutual trade or mutual exchanges of member-states, and lead to increasing well-being. The theory of optimum currency zones [Cohen, 1997, pp. 50-76] (omission of exchange rate costs, currency risks) also applies with economic explanations, the idea of improving production of goods and services because of economies of scale. Functional analysis assumes that states set up various international institutions (including regional) to solve certain functional tasks. According to this view, the strengthening of regional trade and economic relations encourages states to establish institutions that will promote these 
relations to a new level, and thereby raise participant's welfare [Deutch et al., 1957]. There is also evidence that regional integration institutions are to some extent capable to compensate for the "market failures" [Axelrod, Keohane, 1986].

It should be noted that when economic gains to the economy as a whole are recognised from integration, some questions remain unanswered, especially important once for decisionmaking politicians: namely, the relative usefulness of this type of integration for different participants (which country will win the most and which will gain relatively least) and as a result how will the balance of power and wealth change amid participating members. An additional problem is also important - which interest groups are likely to benefit the most in a given state and which are set to lose the most. Last but not least, the question of the relative redistribution amid state and business remains (customs duties). In this particular kind of practical policy, the implications for regional integration schemes may be more important than concerns about the overall benefits of such projects.

To what degree did the Russian politicians comprehend economic gain, when embarking upon the decision to form an integrated unification on the territory of the former Soviet Union? As of the current date, no universal economic method to determine the economic benefits of integration exists, although some calculations for Russian politicians were conducted. During the prospective appraisal of the Eurasian integration, two fundamental methods of gauging the effectiveness of economic integration were used, founded on the general economic equilibrium models and econometric models.

The general equilibrium method is based on the identification and tracking of changes in the equilibrium price of goods and equilibrium production volumes by sectors of the economy. Depending on the variations within these indices, economic agents (producers, consumers or states) will either win or lose. But under the environment of high inflation, market volatility and uncertainty, general equilibrium is difficult to calculate even within one country, never mind for the whole of Eurasia.

Econometric models are more often based on a partial equilibrium method, which limits the sample to a selective calculation of indices in a block configuration. Such models calculate, as a rule, different indicators: tariffs, trade balance, national accounts or the volume of crossborder investment.

The input - output model, prepared by the Centre for development of NRU HSE, has assessed the economic benefits of integration for Russia as nought or a negative sum, whereas for small countries profitability is expected at $1-1.5 \%$. Based on the evaluation of BAM, integration will be somewhat more favourable for Belarus and Kazakhstan and only in the long run may prove to be beneficial for Russia. ${ }^{6}$

According to the model of the Laboratory of Forecasting Macroeconomic and Regional Proportions of the Institute of Economic Forecasting, RAS, the GDP percentage share of the win in 2005-2015 for Russia will amount to a further 6.5\%, for Belarus $8 \%$ and for Kazakhstan about 5\% [Klocvog et al., 2009, pp. 26-36]. But, as the author of the forecast, F. Klotsvog, notes such effect could only be achieved if coherent social, macroeconomic and investment policies, as well as the introduction of overall investment program at the interstate level.

From the references given it is clear that they form one of the models mentioned along with the underlined limitations, with little or no economic benefit being granted for Russia, albeit some gains can be anticipated by its Eurasian partners from the integration.

${ }^{6}$ Avdyeyeva D.A., Akindinova N.V., Volkov M.V., Kondrashov N.V., Mironov V.V., Osipova O.A., Pyetronyevich M.V., Poohov S.G., Soomyenkov V.V, Safarova G.Z. Developing the model of long-term forecast of main macroeconomic indicators of EEU member countries. Available at: http://dcenter.ru/science/ DC_CIS_NIR_2012.pdf (accessed 16 November 2016). (In Russian.) 
Economic results of 2011-2012 somewhat exceeded initial forecasts, although during the ongoing economic crisis it is difficult to judge the degree of realism or stability of growth. It has been reported that during January-September 2012, the volume of the mutual trade in the Customs Union and the Common Economic Space of Russia, Belarus and Kazakhstan amounted to $\$ 51.3$ billion - that is a $9.9 \%$ increase over the January-September 2011 levels. The volume of foreign trade in the CU nations during January-September 2012 amounted to $\$ 689.4$ billion - that is a 5.4\% increase over the January-September 2011. ${ }^{7}$ Later, in 2913 and 2014 trade between the members of the Eurasian Union started to decline due to heavy economic recession, and in 2015 trade had dropped by $26 \%$ compared to the previous year. ${ }^{8}$ A future prospect of economic benefits from integration looks positive, but not staggering in its volumes. Based on the assessment of the Eurasian Development Bank, deepening integration within CES of Russia, Kazakhstan and Belarus, through development of trade ties, production cooperation and alignment of technological development level would result in about a $2.5 \%$ rise in the combined annual GDP of the three countries by 2030 in contrast to no integration. Further, based on the same estimates, the accession of Ukraine into CES could add a further $1 \%$ of forecasted growth during 20 years. ${ }^{9}$

Hence, it is clear that participating economies will gain some benefits due to integration, including Russia, although the volume is quite modest. So, can it be assumed that Russia started this project, which spans 15 years and requires constant attention and assistance from Russian leadership, just to add a few percentage points to its GDP during 20 years, when it could at the same time reach similar or greater rewards through easier means?

Another objective of economic integration projects may be political integration, i.e. the establishment of a regional system of political control that springs from economic cooperation organizations. One view of economic and political integration that has been developed with the use of European material underlines that economic cooperation carries with it the deepening cooperation in politics, even up to the point of unification of political institutions. This approach is illustrated by the economic model of integration by B. Balassa [Nye, 1971].

There is also a very reasoned view that economic integration is propelled primarily by political interests, and they at times become an obstacle to economic integration, even despite the obvious "cash" benefits. This approach not only appears interesting, but also well applicable to the Russian situation, as regional economic integration schemes tend to be decided not so much by the business community as the country's leading political elite. Due to modern Russian foreign policy being largely constructed on the vision of the world from a realist position and of a competitive environment, the primary focus in answering the raised questions should rest on concepts of dependence of vectors on expansion of trade and creation of economic blocs from the mechanisms of collective security connected to the state [Gowa, Mansfield, 1993]. In other words, it has been shown that economic regional groupings are often the product of military and political cooperation, and that governments are more likely to liberalize their trade with political allies than rivals. This explanation rests well with the realities of interaction amid Russian, Kazakhstan and Belarus, and as it appears to some extent it reflects the driving force of Russian integration policy. Russia's main contribution to further Eurasian integration has taken the form of security provisions which became valuable and desired with the advance of

\footnotetext{
${ }^{7}$ Vishnjakov A. Who will catch Eurasian Economic Union. Available at: http://www.vrns.ru/analytics/ 758/\#.UMhzxeR1HTo (accessed 16 November 2016). (In Russian.)

${ }^{8}$ Eurasian Economic Commission, October, 2015. Available at: http://www.eurasiancommission.org/ru/ act/integr_i_makroec/dep_stat/tradestat/analytics/Documents/express/Oct2015.pdf (accessed 16 November 2016). (In Russian.)

${ }^{9}$ See: http://www.eabr.ru/general//upload/reports/Ukraina-resume.pdf (accessed 16 November 2016). (In Russian.)
} 
ISIS towards Eurasian borders in 2014-2015. But, the possible presumption that Russia is in all seriousness incentivising economic integration of the post-Soviet space in the bid to restore political unity under its control, simply does not reflect with reality. For instance, history of political relations amid Russia and Belarus leaves no room for doubt, as Belarus is not prepared to undertake even the slightest sacrifice of its political sovereignty while Russia is well aware of the position of the post-Soviet elites.

The third crucial point for analysis of the role and functions of regional associations and origins of Russian regional policy is the understanding of the region as a subsystem that is both formulated and controlled by the regional hegemonic-power, and is its political and economic resource in the global system. In contrast to the global system, a regional system is not closed and under an analysis of the relationship formulated within the system, it is pivotal to recognise the presence of external factors with militarily-political and financially-economic characteristics. Nevertheless, in the centre the regional leader can be found who wields both the capacity and the resolve to build regionally systemic political, economic and financial architecture.

The regional political and military hegemon applies the policy of regional economic integration based on two crucial stimuli.

Foreign trade generates gains in economic efficiency and that can be used as a way to strengthen military and political power of the state. For this reason, regional hegemon has little interest in expanding trade with potential rivals and, on the contrary, interest exists in creating regional association that will separate the rival with a common customs tariff. Establishing this kind of tariff is intended to redistribute the winnings from trade in favour of the Customs Union organising power. Another stimulus is that by commercially aiding political allies, strengthens the overall union and additionally its leader [Mansfield, Milner, 1997].

Naturally similar mechanisms also operate within the framework of regional monetary integration projects - i.e. currency zones. In parallel with geographical increase of the area in which a currency is used, the zone of political influence of a state also increases which imposes that currency. The remaining state-participants of the currency zone become depended on the financial stability of the state-hegemon, in turn, the state-hegemon is not free as it is limited by financial politics - as the local core for the regional financial system is obligated to maintain the credibility of its currency and pursue a stable monetary policy.

Hence, in this manner, economic integration projects allow Russia to address objectives which lie not only in the sphere of pure economics.

The instigation of a REO means establishing a market with a large capacity that can be the basis for a more stable global and crisis prone economic development, and thus strengthening the sovereignty of Russia and the entire regional sphere.

The implementation of such a market would lead to greater use of local currencies, including the ruble, instead of dollars and euros, and thin the channels of inflow of economic shocks on Russia and other participating-states. In addition, such development will allow for a spectrum of financial services to expand in rubles, which in turn, will allow for funds to be made by taking away a portion of control from foreign financial services.

The creation of the single market would mean better prospects for domestic producers.

At the political level, the establishment of a regional economic bloc will mean further strengthening of political bonds among participants. A daily mechanism will appear that will harmonise both financially-economic and political interests. The REO area will be less prone to external political pressure, which could arise from economic instruments (sanctions, politically associated credits). The new economic integration centre will be strengthened and thus in turn political influence.

The concept of regional dominance allows for political incentives of "small" states within the region to be identified and to incentivise their accession into the regional economic body 
with a great state: legitimising local ruling regimes, granting of informal guarantees of military protection, shared supranational institutions with the integrator offer the opportunity through participation to adopt collective decision making restraining expansive desires of the integrator, trade of partial sovereignty for real economic benefits. Russia's interests, in part, reveal that the benefit of economic integration allows the integrator to employ the funds to strengthen their own economic muscle and, as a result, politic and military supremacy; the integrator could become the issuers of regional currency, which will expand its zone of political influence.

A proposed opinion on the origins of the Russian integration policy, proposes that Russia began to create regional economic integrations to strengthen its global position in the politicaleconomic system. With such policy Russia is trying to reinforce its competitive position within the global system, in response to the challenge raised by V.V. Putin as "the next few years will be a turning point, not only for Russia. We are awaited by the era of upheaval. Competition is growing, not only for raw materials, but also human capital. The internal energy of states will decide all. Consumption growth has become a habit. This is not bad, but it can only be upheld with access to new technological order. Share of the global pie for those nations falling behind will be substantially less than for the leaders." 10

The immediate objectives for Russia in the creation of REO are to increase income for its economy, stabilization of economic growth by expanding the sales markets and stabilizing the monetary system by expanding the zone that uses the ruble. Consequentially, there will be other, more specific benefits from such projects. If successful, these policies will lead to the stabilization of the nation's economic growth, strengthen its position in the global monetaryfinancial system and reinforce its political sovereignty with more economic autonomy. These projects do not have a direct goal of recreating a new version of the USSR, but contribute to the consolidation of the post-Soviet space on an economic basis.

\section{The Western Understanding of Eurasian Integration}

American and EU policies towards post-Soviet integration as such, is still formulating. On the one hand, it has certain inertia and a foundation, based on weakening Russian influence on the former post-Soviet space: ripping apart the post-Soviet states into various projects, blocs and coalitions, formed around political (like GUAM), gas (pipelines bypassing Russia), military (bases in Central Asia), poli-technological (colour revolutions) and similar initiatives. This approach has been initiated all the way back from 1990-ies and with more or less vigour holds to this day. It should be noted that a series of crisis, specifically the Ukrainian collision of two integration schemes - European and Eurasian - has made the relationships more conflictual and precluded the substantial dialogue between Russia and the West on the future of Eurasian integration.

At the same time, there is a growing awareness in American and European politics of the fact that in the post-Soviet space a new actor is rising - or has already emerged - unlike anything before as it incorporates Russia, Kazakhstan, Belarus, Armenia and Kirgyzstan. New reality is being increasingly accepted and influential European politicians indicate the readiness to start dialogue between EU and Eurasian Union. ${ }^{11}$

${ }^{10}$ V. Putin, Address to the Federal Assembly, December 12, 2012. Available at: http://www.rbcdaily. ru/2012/12/12/focus/562949985314962 (accessed 16 November 2016) (In Russian.)

${ }^{11}$ Von C.C. Malzahn, Silke Mülherr, Daniel Friedrich Sturm "Europäische Friedensordnung steht auf dem Spiel”, 16.11.14. Available at: http://www.welt.de/politik/deutschland/article134378688/EuropaeischeFriedensordnung-steht-auf-dem-Spiel.html (accessed 16 November 2016). 
The rather humble analytical baggage, with which the United States and EU have approached this point, does not contain an understanding of the future role of the Eurasian Union: its place in regional and world politics and economics, global and regional institutions. The conceptions of the mounting Russian influence in Central Asia [Buszynski, 2005] or the expulsion of the United States from there [Gleason, 2006], as many American experts have argued [Boh, 2004], can no longer be used to explain the current situation.

Without a doubt, the new American administration will employ its own understanding of the American interests and its own procedural vision during formulation of its policy towards the post-Soviet space and future developments within the territory of ex-USSR. As of now, the United States and EU lack the full understanding of these processes, and alike, the understanding of what Russia is trying to construct in the post-Soviet space. Western estimates have a broad diapason - the reference by the United States Assistant Secretary describes the Eurasian Union as "an idea that is on paper so far, ${ }^{12}$ " whereas some contemplate this as a plan to resurrect the USSR (Hillary Clinton). Both of these estimates are imprecise, as can be supported in the profile articles of V. V. Putin: "First, we are not talking about that in one form or another to recreate the Soviet Union. It would be naive to try to restore or copy what is left in the past, but the tight integration to the new value, the political, economic basis - is imperative. ${ }^{13}$ "

The intellectual problem, however, lies in the fact that Russia has repeatedly explained that it is building a - Customs Union, Eurasian Economic Space, the Eurasian Union - but it has never clearly explained why it is doing it. To be precise, the clarifications of Russian objectives in creating regional unifications were given and in part are cited in the above presidential article, but these explanations carry completely liberally intentions and loosely coupled with mainly realistic foreign policy of the Russian leadership. Officially, Russia claims, that the goal is of economic nature (expand the market, increase turnover), but not many politicians or experts believe that Russian interests are so limited.

A marked conceptual contradiction and uncertainty is obvious to foreign observers. There is a growing recognition that Russia had started something very ambitious. However, the exact contours of this project are not yet entirely clear and Western politicians cannot determine how far Russian plans in Eurasia contradict American and European interests, how close Russian interests match with the Chinese and whether they need to counteract. For observers, the focal purpose of the Russian strategy remains blurred - to what extent is Russian policy focused on fighting for markets, profit for their firms and for overall growth of its economy, and - to what degree to construct in Eurasia a regional political-economic subsystems with the centre in Moscow; the new regional power centre.

How will the West build its position relative to Russia's Eurasian project? The conservative magazine The National Interest proposes to wait and not to take any actions just yet. The author argues that if the outcomes are narrowed to simply an increase of trade amid Russia and countries of the Central Asia, then there is nothing wrong. Importantly, as the author warns, Moscow must not begin to intercept the foreign policy course of the member-states of the Eurasian Union [Mankoff, 2012]. But, as it seems apparent, Moscow does not plan to do this! To a large degree plans are focused on creating a strong regional economic bloc that will configure regional finances, trade and investments in the interests of regional nations, first and foremost Russia, and not in the interest of outside powers.

${ }^{12}$ Robert O. Blake, Jr., Assistant Secretary, Bureau of South and Central Asian Affairs, Washington, DC., March 25, 2012. Interview With Al Jazeera TV. Available at: http://www.state.gov/p/sca/rls/rmks/2012/187005. htm (accessed 16 November 2016).

${ }^{13}$ Article by Prime Minister Vladimir Putin "A new integration project for Eurasia: The future in the making." Available at: http://www.russianmission.eu/en/news/article-prime-minister-vladimir-putin-newintegration-project-eurasia-future-making-izvestia-3-\#sthash.VjwhNryq.dpuf (accessed 16 November 2016). 
Will the EU and United States accept this perspective or will they oppose it? Most probably, they will both acknowledge it and oppose it. But, the opposition must not undertake an overly aggressive tone, as Russian projects create only a threat to American future gains in quite a far and unstable corner of the world. In all, this would fit within the frame of rules of the game that have been put forward by United States itself. Also, Russia's actions do not create a military threat for anybody, and in contrast they could contribute to the stabilization of quite a problematic region.

The success of the Russian project would also mean strengthening of Russia's position during negotiations about the reforms of the world's financial architecture, commerce, climate and other vital issues. Will the United States and EU react to such strengthening of the Russian stance as undesirable? Not necessarily. If the Russian stance on global issues is constructive, then presence of additional resources and political influence may even be useful amidst the process, and in some areas even for the United States and United Europe.

\section{References}

Axelrod R., Keohane R. (1986) Achieving Cooperation under Anarchy: Strategies and Institutions. Cooperation under Anarchy (ed. K.F. Oye). Princeton.

Boh A. (2004) Regionalism in Central Asia: New Geopolitics, Old Regional Order. International Affairs, vol. 80 , no 3, pp. 485-502.

Buszynski L. (2005) Russia's New Role in Central Asia. Asian Survey, vol. 45, no 4, pp. 546-565.

Cohen B. (1997) The Political Economy of Currency Regions. The Political Economy of Regionalism (eds. D. Mansfield, H. Milner ), pp. 50-76.

Deutch K.W., Burrell S.A., Kann R.A., Lee M. (1957) Political Community and the North Atlantic Area: International Organization in the Light of Historical Experience. Princeton.

Gleason G. (2006) The Uzbek Expulsion U.S. Forces and in Central Asia. Problems of Post-Communism, vol. 53, no 2, pp. 49-60.

Gowa J., Mansfield E. (1993) Power Politics and International Trade. American Political Science Review, vol. 87 , pp. $408-420$.

Klocvog F.N., Suhotin A.B., Chernova L.S. (2009) Prognozirovanie jekonomicheskogo razvitija Rossii, Belarusi, Kazahstana i Ukrainy v ramkah edinogo jekonomicheskogo prostranstva (Prediction of Economic Development of Russia, Belarus, Kazakhstan and Ukraine in the Common Economic Space). Problemy prognozirovanija, no 4, p. 26-36. Available at: http://www.ecfor.ru/pdf.php?id=2009/4/02 (accessed 19 May 2016). (In Russian.)

Krugman P. (1993) Regionalism versus Multilateralism: Analytical Notes. New Dimensions in Regional Integration (eds. De Melo J., Panagariya A.), pp. 58-89.

Lipsey R. (1960) The Theory of Customs Unions: A General Survey. Economic Journal, vol. 70, pp. 496-513.

Mankoff J. (2012) What a Eurasian Union Means for Washington. National Interest, 19 April. Available at: http://nationalinterest.org/commentary/what-eurasian-union-means-washington-6821 (accessed 19 May 2016).

Mansfield D., Milner H. (1997) The Political Economy of Regionalism. N.Y.

Meade J.E. (1955) The Theory of Customs Unions. Amsterdam.

Nye J.S. (1971) Peace in Parts: Integration and Conflict in Regional Organization. Boston.

Palan R. (2007) Transnational Theories of Order and Change: Heterodoxy in International Relation scholarship. Review of International Studies, vol. 33, Supplement (Critical International Relations Theory after 25 years), April, pp. 47-69.

Viner J. (1950) The Customs Union Issue. N.Y. 